\title{
ANALISIS INVESTASI SEKTOR PERTANIAN DI SULAWESI TENGGARA
}

\author{
Azhar Bafada \\ Jurusan Agribisnis Faperta Unhalu, Kendari \\ azharbafadal@yahoo.com
}

\begin{abstract}
This study aims to compare theinvestment on agriculture sector in Southeast Sulawesi. Data used are of annually, covering 1990-2009. The analysis is undertaken by using a multiple regression. The result shows that the interest rate of credit, the Gross Regional Domestic Producton agriculturesector simultanaeously to give significant effect to theinvestment on agriculturesector. The value of regression coefficient of the interest rate credit is negative, but the interest rate of credit does not provide a significant to the investment on agriculture sector. Meanwhile, the Gross Regional Domestic Product on agriculture sector has a positive relationship and has a significantto the investment on agriculture sector. The value of regression coefficientby 0,191 indicates that when the GRDP on agriculture sector increase by 1 rupiahwill increase investment on agriculture sector by 0,191 rupiah, or when agriculture GRDP increased by 1\% then will improve the investment on agriculture sector of 0,97\%, or more easily can be defined that if the GRDP of agriculture sector increase, the investment of the agriculture sector will also be increase.
\end{abstract}

Keywords: GRDP, Interest Rate, Investment, Regional Autonomy

\section{PENDAHULUAN}

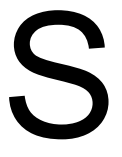

ektor pertanian mempunyai peranan yang penting dalam perspektif ekonomi makro. Hal ini disebabkan karena pertama, sektor pertanian merupakan sumber pertumbuhan output nasional yang penting. Data BPS menunjukkan bahwasektor ini memberikan kontribusi 19,1\% terhadap Produk Domestik Bruto (PDB) dari keseluruhan sektor perekonomian Indonesia. Walaupun secara absolut lebih kecil jika

$$
\text { QE Journal | Vol.02 - No.04 - } 1
$$


dibandingkan dengan kontribusi sektor jasa (43,5\%) dan manufaktur $(23,9 \%)$. Tetapi sektor pertanian merupakan sektor yang menyerap tenaga kerja terbesar yakni 47,1\%.

Kedua, sektor pertanian memiliki karakteristik spesifik khususnya dalam hal ketahanan sektor ini terhadap guncangan struktural dari perekonomian makro. Pada saat krisis ekonomi pertumbuhan PDB negatif sepanjang triwulan pertama tahun 1998 sampai triwulan pertama tahun 1999, namun sektor pertanian tetap bisa tumbuh dimana pada triwulan pertama dan triwulan ketiga tahun 1998 pertumbuhan sektor pertanian masing-masing 11,2\%, sedangkan pada triwulan pertama tahun 1999 tumbuh menjadi 17,5\%. Adapun sektor non pertanian pada periode krisis ekonomi pertumbuhannya adalah negatif.

Sampai saat ini sektor pertanian masih merupakan tulang punggung dalam menopang perekonomian Sultra. Hal itu dibuktikan betapa sektor pertanian (dalam arti luas) secara agregat memberikan kontribusi pada PDRB berdasarkan harga berlaku sebesar 42,37\% pada tahun 2005 dan 35,02\% pada tahun 2009 (Tabel 1). Peranan sektor pertanian tampaknya dalam jangka pendek belum akan dapat digeser oleh sektor lain dalam sumbangsihnya pada output Sultra. Hal itu disebabkan peranan sektor yang lain masih jauh di bawah sektor pertanian. Apabila dirata-ratakan dari tahun 2005-2009, sektor pertanian memberikan kontribusi terbesar terhadap PDRB yaitu sebesar 38,54\%.

Tabel 1. Peranan Sektor Pertanian dalam PDRBSulawesi Tenggara Atas Dasar Harga Berlaku, Tahun 2005 - 2009 (\%)

\begin{tabular}{|c|c|c|c|c|c|}
\hline Sektor & 2005 & 2006 & 2007 & 2008 & 2009 \\
\hline 1. Pertanian & 42,37 & 40,73 & 38,12 & 36,44 & 35,02 \\
\hline 2. Pertambangandanpenggalian & 4,53 & 4,05 & 4,81 & 4,60 & 4,28 \\
\hline 3. Lndustripengolahan & 5,78 & 6,85 & 7,90 & 7,62 & 6,43 \\
\hline 4. Listrikdan air bersih & 1,05 & 1,01 & 0,94 & 0,87 & 0,93 \\
\hline 5. Kons truksi/bangunan & 6,79 & 6,72 & 6,92 & 7,40 & 7,72 \\
\hline 6. Perdagang, hotel danrestoran & 14,22 & 14,06 & 15,22 & 16,26 & 17,45 \\
\hline 7. Pengangkutandankomunikasi & 7,45 & 7,61 & 8,17 & 8,46 & 9,26 \\
\hline 8. Keuangan, perse waandanjasa pe rusahaan & 4,62 & 5,31 & 5,04 & 5,38 & 5,30 \\
\hline 9. Jasa-jasa & 13,19 & 13,33 & 12,88 & 12,97 & 13,61 \\
\hline
\end{tabular}

Sumber : BPS, 2010

QE Journal | Vol.02 - No.04 - 2 
Melihat pentingnya peranan sektor pertanian, maka dibutuhkan suatu kebijakan yang dapat mendorong peningkatan di sektor tersebut. Sementara untuk mencapai peningkatan produksi, maka investasi dalam jumlah yang mencukupi kapasitas perekonomian merupakan hal yang perlu untuk mendapat perhatian.

Dari uraian tersebut, maka jelaslah bahwa investasi atau penanaman modal yang dilakukan oleh pihak swasta sangat dibutuhkan. Sehingga untuk meningkatkan investasi tersebut maka kita perlu mengetahui faktor-faktor yang mempengaruhi investasi, baik itu faktor ekonomi maupun faktor non ekonomi. Dimana faktor ekonomi adalah tingkat suku bunga dan pendapatan regional, sedangkan faktor non ekonomi salah satunya adalah kebijakan pemerintah.

Tingkat suku bunga merupakan salah satu faktor yang mempengaruhi investasi. Hal ini sejalan dengan pendapat Soediyono (1992), pengaruh tingkat bunga terhadap besarnya investasi suatu masyarakat, baik menggunakan pendekatan yang sederhana maupun pendekatan yang lebih modern menghasilkan kesimpulan yang sama, bahwa investasi merupakan fungsi tingkat bunga dengan korelasi negatif. Hal tersebut menyebabkan bahwa meningkatnya tingkat bunga (r)mengakibatkan berkurangnya pengeluaran investasi, dan sebaliknya menurunnya tingkat bunga mengakibatkan bertambahnya tingkat investasi.

Investasi juga dipengaruhi oleh pendapatan nasional (regional), hal ini sejalan dengan pendapat Suparmoko (2000), tingkat investasi merupakan fungsi linear dari tingkat pendapatan nasional (regional), sehingga investasi akan meningkat bila pendapatan nasional (regional) juga meningkat namun dengan proporsi yang lebih kecil daripada peningkatan pendapatan nasional (regional).

Secara umum, tujuan penelitian ini adalah melakukan analisis investasi sektor pertanian di Sulawesi Tenggara. Secara khusus, tujuan penelitian ini adalah menganalisis pengaruh tingkat suku bunga kredit, Produk Domestik Regional Bruto (PDRB) sektor pertanian terhadap investasi sektor pertanian di Sulawesi Tenggara.

Investasi pada dasarnya merupakan salah satu aspek yang sangat penting dalam kegiatan pembangunan suatu daerah, hal ini disebabkan karena melalui investasi dapat diciptakan kesempatan kerja yang lebih besar bagi

QE Journal | Vol.02 - No.04 - 3 
masyarakat sehingga dapat mengurangi pengangguran serta peningkatan kapasitas dan produksi dalam negeri dalam jangka panjang, investasi tersebut dapat mengoptimalkan pemanfaatan segala sumberdaya yang dimiliki sehingga akan meningkatkan pendapatan baik itu bagi daerah maupun bagi masyarakat luas.

Investasi adalah produksi barang-barang bukan untuk konsumsi sekarang. Barang-barang seperti itu dinamakan barang investasi. Barang-barang tersebut diproduksi perusahaan-perusahaan dan mungkin dibeli oleh perusahaan lain atau oleh rumah tangga. Sebagian besar investasi oleh perusahaan dapat menanamkan modalnya dalam bentuk barang-barang persediaan (inventaris) maupun dalam bentuk barang modal seperti tanaman dan peralatan. Investasi dapat diartikan sebagai pengeluaran atau pembelanjaan penanam- penanam modal atau perusahaan untuk membeli barang-barang modal dan perlengkapan-perlengkapan produksi untuk menambah kemampuan memproduksi barang-barang dan jasa-jasa yang tersedia dalam perekonomian (Sukirno, 1994).

Rahardja dan Mandala (2005), menyatakan bahwa dengan membatasi investasi fisik, misalnya dalam bentuk barang modal (pabrik dan peralatan), bangunan dan persediaan barang (inventory) maka definisi investasi dapat lebih dipertajam sebagai pengeluaran-pengeluaran yang meningkatkan stok batang modal (capital stock). Stok barang modal (barang modal yang tersedia) adalah jumlah barang modal dalam suatu perekonomian, pada satu saat tertentu. Dornbuch dan Fischer (1987), menyatakan bahwa investasi memerlukan beberapa definisi. Salah satunya, investasi berarti penambahan persediaan fisik modal. Sementara kita menganut istilah ini, investasi tidak mencakup pembelian surat obligasi Jasa Marga, pembelian saham PT Unilever Indonesia, investasi mencakup pembangunan kontruksi rumah, pembuatan mesin, kontruksi pabrik dan menambah persediaan barang perusahaan.

Ada dua peran yang dibawa oleh investasi dalam makro ekonomi. Pertama, investasi merupakan komponen pengeluaran yang cukup besar dan berubah-ubah. Dengan demikian perubahan besar dalam investasi akan sangat mempengaruhi permintaan agregat dan akhirnya akan berakibat juga pada output dan kesempatan kerja. Kedua, investasi menghimpun akumulasi modal. Dengan membangun sejumlah gedung dan peralatan yang berguna, output potensial suatu bangsa bertambah,

QE Journal | Vol.02 - No.04 - 4 
dan pertumbuhan ekonomi jangka panjang juga akan meningkat. Jelas dengan demikian bahwa investasi memainkan dua peran dalam menentukan jumlah output dan pendapatan (Samuelson dan William, 1997).

Menurut Deliarnov (1995), investasi merupakan komponen pengeluaran agregat kedua sesuadah konsumsi. Investasi bersumber dan dana masyarakat yang ditabung melalui lembaga-lembaga keuangan, untuk kemudian disalurkan kepada perusahaan-perusahaan. Kalau konsumsi dikeluarkan rumah tangga untuk membeli barang-barang dan jasa untuk mendapatkan kepuasaan (utility), maka investasi ditanamkan oleh perusahaan-perusahaan dalam usaha memperoleh laba (profit) yang sebesar-besarnya.

Berdasarkan pendapat para ahli seperti diuraikan di atas, dapat disimpulkan bahwa investasi adalah keseluruhan pengeluaran ekonomi manusia yang bertujuan untuk menciptakan produksi dan menambah modal pada pada waktu tertentu misalnya bangunan, peralatan produksi dan persediaan stok barang, dimana tujuan akhirnya adalah untuk meningkatkan keuntungan. Dengan peningkatan investasi maka dapat meningkatkan pendapatan nasional.

Sukimo (1999), memgemukakan bahwa faktor-faktor utama yang menentukan tingkat investasi adalah:

1. Tingkat keuntungan investasi yang diramalkan akan diperoleh

2. Tingkat bunga

3. Ramalan mengenai keadaan ekonomi di masa depan

4. Kemajuan teknologi

5. Tingkat pendapatan nasional dan perubahan-perubahannya

6. Keuntungan yang diperoleh perusahaan-perusahaan.

Partadiredja (1985), menyatakan bahwa salah satu faktor yang mempengaruhi investasi adalah pendapatan nasional. Makin tinggi pendapatan nasional makin tinggi pula pengeluaran konsumsi. pengeluaran konsumsi yang makin tinggi memerlukan produksi barangbarang konsumsi yang lebih banyak. Produksi barang-barang konsumsi yang lebih banyak memerlukan barang-barang modal yang lebih banyak pula. Lain daripada itu kenaikkan pendapatan nasional akan membangkitkan harapan (expectation) pengusaha untuk memperoleh

QE Journal | Vol.02 - No.04 - 5 
untung dari kenaikkan volume usaha. Harapan ini pula yang mendorong pengusaha untuk menambah modal.

Suparmoko (2000), menyatakan bahwa selain tingkat suku bunga, ada faktor lain yang mempengaruhi tinggi rendahnya tingkat investasi yang pendapatan nasional. Semakin tinggi tingkat pendapatan nasional, semakin tinggi pula tingkat investasi. Oleh karena itu terdapat hubungan yang positif antara tingkat investasi dan tingkat pendapatan nasional. Sehingga investasi merupakan fungsi dari tingkat suku bunga dan pendapatan nasional $\mathrm{I}=\mathrm{f}(\mathrm{r}, \mathrm{Y})$. Hubungan antara investasi (I) dan tingkat suku bunga (r) adalah negatif.

Pemberian hak otonomi pada setiap daerah, yang mulai diberlakukan tanggal 1 Januari 2001 dapat meningkatkan investasi di setiap daerah (provinsi). Hal ini disebabkan karena pengusaha-pengusaha (investor) tidak lagi menghadapi birokrasi yang berbelit-belit. Hal ini sejalan dengan pendapat Deliarnov (1995), jika pemerintah banyak memberikan kemudahan-kemudahan bagi pengusaha (investor), tingkat investasi akan tinggi. Tetapi jika situasi politik tidak aman dan pengusaha banyak menghadapi birokrasi yang berbelit-belit maka tingkat investasi akan rendah.

Dengan adanya otonomi daerah maka dapat memudahkan investor karena keputusan investasi ditentukan oleh persetujuan pemerintah daerah, tidak seperti sebelum otonomi daerah, dimana setiap keputusan harus disetujui terlebih dahulu oleh pemerintah pusat, sehingga investor membutuhkan waktu yang lama untuk merealisasikan investasi tersebut. Hal ini sejalan dengan pendapat Kuncoro (2004), setelah pemerintah pusat memberikan hak otonomi setiap daerah maka pemerintah daerah bertanggung jawab sepenuhnya terhadap peraturan investasi sesuai dengan keadaan daerah tersebut.

Keperluan akan investasi sangat penting dibutuhkan untuk memacu pertumbuhan ekonomi terutama investasi yang dilakukan pada sektor pertanian akan dapat menciptakan kesempatan kerja.Penanaman modal merupakan langkah awal kegiatan produksi. Dengan posisi semacam itu, investasi hakekatnya juga merupakan langkah awal kegiatan pembangunan ekonomi. Dinamika penanaman modal mempengaruhi tinggi rendahnya pertumbuhan ekonomi, mencermin marak lesunya 
pembangunan. Dalam upaya menumbuhkan perekonomian, setiap negara senantiasa berusaha menciptakan iklim yang dapat menggairahkan investasi. Sasaran yang ditujukan bukan hanya masyarakat atau kalangan swasta dalan negeri, tetapi juga investor asing. Demikian pula halnya Indonesia (Dumairy, 1996).

Tambunan (2003), menyatakan bahwa berdasarkan teori pertumbuhan ekonomi dan Harrod-Domar yang menerangkan adanya korelasi positif antara distnbusi investasi langsung (I) dan laju pertumbuhan ekonomi, dapat dikatakan bahwa kurangnya (I) di suatu wilayah membuat pertumbuhan ekonomi dan tingkat pendapatan masyarakat perkapita di suatu wilayah tersebut rendah, karena tidak ada kegiatan-kegiatan ekonomi yang produktif seperti industri manufaktur.

Peranan investasi menurut Sukirno (1994) adalah kegiatan investasi memungkinkan suatu masyarakat terus menerus meningkatkan kegiatan ekonomi dan kesempatan kerja, peranannya ini bersumber dari tiga fungsi penting dari kegiatan investasi dalam perekonomian. Pertama, investasi merupakan salah satu komponen dari pengeluaran agregat dan pendapatan nasional. Peningkatan seperti ini akan selalu diikuti oleh pertambahan dan kesempatan kerja. Kedua, pertambahan modal sebagai akibat investasi akan meningkatkan kapasitas memproduksi dimasa depan dan perkembangan ini akan mentimulir pertambahan produksi nasional dan kesempatan kerja. Ketiga, investasi selalu diikuti oleh perkembangan teknologi. Perkembangan ini akan memberi sumbangan penting terhadap kenaikkan produktivitas dan pendapatan perkapita masyarakat.

Dengan semakin meningkatnya investasi khususnya di sektor pertanian di suatu daerah maka dapat meningkatkan pendapatan daerah tersebut karena pendapatan perkapita meningkat, sebagai akibat dari meningkatnya lapangan pekerjaan (mengurangi penganguran) sehingga dapat menciptakan kemakmuran (kesejahteraan) masyarakat. Dengan meningkatnya kesejahteraan masyarakat maka akan menciptakan keamanan di daerah (negara) tersebut. Maka untuk mencapai hal tersebut dibutuhkan iklim investasi yang kondusif. Menurut Pangaribuan $d k k$ (2005), langkah-langkah untuk mendorong investasi sektor pertanian antara lain : menyederhanakan prosedur investasi, peningkatan kepastian hukum, serta perbaikan kualitas infrastruktur. Selain itu pemerintah melalui Departemen Pertanian dapat memberikan beberapa insentif 
kepada investor di sektor pertanian antara lain : bantuan informasi dan teknologi, bantuan untuk melakukan studi kelayakan. Insentif dapat juga dalam bentuk kerinan pajak dan akan lebih berarti lagi bila diberi tax holiday.

\section{METODE PENELITIAN}

Data yang digunakan dalam penelitian adalah data time seriestahun 19902009. Data tersebut diperoleh dari Badan Pusat Statistik, Penanaman Modal Daerah Provinsi Sulawesi Tenggara dan Bank Indonesia Kendari.Analisis dilakukan dengan menggunakan regresi linear berganda (Koutsoyiannis. 1977 danThomas, 1995).Pengolahan data dengan menggunakan perangkat lunak (software) komputer program Microsof Excel dan estimisi model menggunakan bantuan softwareStatistic Analysis Sistem (SAS) versi 6.12. Pengujian parameter dilakukan pada tingkat kepercayaan $95 \%(\alpha=0,05)$. Secara matematis persamaan tersebut dapat dituliskan sebagai berikut:

$$
Y=a+b X+b X+e
$$

Dimana :

$$
\begin{aligned}
& \mathrm{Y}=\text { Investasi sektor pertanian (Rp) } \\
& \mathrm{a}=\text { Konstanta } \\
& \mathrm{b}=\text { Koefisien regresi } \\
& \mathrm{X}_{1}=\text { Tingkat suku bunga kredit }(\%) \\
& \mathrm{X}_{2}=\text { PDRB sektor Pertanian }(\mathrm{Rp}) \\
& \mathrm{e}=\text { Error term }
\end{aligned}
$$

Tanda parameter dugaan yang diharapkan adalah $\mathrm{b}_{1}<0$, artinya bahwa variabel $X_{1}$ dan $Y$ mempunyai hubungan negatif. Sedangkan $b_{2}>0$, artinya bahwa variabel $\mathrm{X}_{2}$ dan $\mathrm{Y}$ mempunyai hubungan yang positif.

Koefisien regresi diduga dengan menggunakan metode jumlah kuadrat terkecil (ordinary least squares method). Untuk mengetahui pengaruh variabel bebas $(\mathrm{X})$ terhadap variabel tak bebas (Y), secara simultan dilakukan dengan uji F sebagai berikut. Dalam penelitian ini menggunakan program komputer Statistic Analysis Sistem (SAS) versi 6.12 sehingga indikator yang digunakan adalah :

QE Journal | Vol.02 - No.04 - 8 
1. Jika probabititas Fhitung taraf nyata yang digunakan $(\alpha=0,05)$, maka menunjukkan variabel bebas $(X)$ secara bersama-sama berpengaruh nyata terhadap variabel tak bebas (Y).

2. Jika probabilitas Fhitung $>$ taraf nyata yang digunakan $(\alpha=0,05)$, maka menunjukkan variabel bebas $(X)$ secara bersama-sama berpengaruh tidak nyata terhadap variabel tak bebas (Y).

Untuk mengetahui besarnya pengaruh dari masing-masing variabel bebas (X) terhadap variabel tak bebas ( $\mathrm{Y}$ ) dilakukan uji $\mathrm{t}$ dengan persamaan sebagai berikut. Dengan menggunankan software SAS Versi 6.12 maka untuk menguji apakah setiap variabel bebas $(X)$ berpengaruh terhadap variabel tak bebas (Y) maka digunakan kriteria sebagai berikut:

1. Jika probabititas thitung $<$ taraf nyata yang digunakan $(\alpha=0,05)$, maka menunjukkan variabel bebas $(X)$ secara parsial berpengaruh nyata terhadap variabel tak bebas (Y).

2. Jika probabilitas thitung $>$ taraf nyata yang digunakan $(\alpha=0,05)$, maka menunjukkan variabel bebas $(X)$ secara parsial berpengaruh tidak nyata terhadap variabel tak bebas $(\mathrm{Y})$.

\section{HASIL DAN PEMBAHASAN}

Untuk mengetahui faktor yang mempengaruhi investasi di sektor pertanian maka dilakukan analisis regresi linear berganda. Pengolahan data menggunakan perangkat lunak (software) komputer program Microsof Exel dan estimsasi model dengan bantuan perangkat lunakStatistic Analysis Sistem (SAS) versi 6.12. Pengujian parameter dilakukan pada tingkat kepercayaan $95 \%(\alpha=0,05)$. Dari hasil estimasi model maka diperoleh persamaan fungsi regresi linear berganda sebagaimana ditunjukkanpadaTabel 2.

Tabel 2. Nilai Parameter Dugaan

\begin{tabular}{lcc}
\hline \multicolumn{1}{c}{ PeubahPenjelas $(\mathrm{X})$} & KoefisienRegresi $(\mathrm{b})$ & Probabilitas $>\mathrm{T}$ \\
\hline Intercep & 644866 & 0,0081 \\
Tingkat Suku Bunga Kredit & -25204 & 0,133 \\
PDRB Sektor Pertanian & 0,191 & 0,0081 \\
\hline KoefisienDeterminasi $\left(\mathrm{R}^{2}\right)$ & 0,71 & \\
\hline
\end{tabular}

QE Journal | Vol.02 - No.04 - 9 
Dengan demikian, maka model tersebut adalah:

$$
Y=644866-25204 X+0,191 X
$$

Dari persamaan di atas dapat dilakukan pengujian terhadap model yang digunakan dan terhadap variabel bebas.Pengujian hipotesis variable bebas digunakan untuk melihat pengaruh variable bebas $(X)$ secara parsial terhadap variable takbebas (Y) dengan menggunakan uji t.

Untuk menguji model regresi linear berganda yang digunakan, maka dilakukan dengan uji F. Berdasarkan hasil analisis, diperoleh nilai Fhitung sebesar 6,324dengan tingkat probabilitas sebesar 0,0092pada taraf kesalahan $5 \%(\alpha=0,05)$. Karena probabilitas Fhitung 0,0092lebih kecil dari taraf nyata yang digunakan $(\alpha=0,05)$, maka sesuai dengan kriteria pengambilan keputusan $\mathrm{H}_{0}$ ditolak dan $\mathrm{H}_{1}$ diterima, hal ini berarti bahwa seluruh variabel bebas $(X)$ yang dimasukkan ke dalam model, secara bersama-sama menunjukkan pengaruh yang nyata terhadap investasi sektor pertanian di Sulawesi Tenggara atau variabel tak bebas (Y).

Hasil analisis tersebut, diperoleh nilai koefisien determinasi $\left(\mathrm{R}^{2}\right)$ sebesar 0,71 yang berarti bahwa $71 \%$ keragaman variabel tak bebas (Y) secara serentak dapat dijelaskan oleh keragaman variabel bebas $(X)$, dan sisanya 29 \% dijelaskan oleh keragaman variabel lain yang tidak dimasukkan ke dalam model. Koefisien korelasi (R) digunakan untuk mengetahui derajad keeratan hubungan antara variabel tak bebas (Y) dengan variabel-variabel bebas $(X)$. Hasil analisis diperoleh nilai koefisien korelasi (R) adalah sebesar 0,84 dengan tanda positif dan mendekati angka satu, maka dapat dikatakan bahwa antara variabel tak bebas (Y) mempunyai hubungan yang erat atau kuat dengan seluruh variabel bebas $(X)$. Dengan demikian, model regresi linear berganda tersebut dapat digunakan untuk menjelaskan hubungan antara variabel tak bebas (Y) dengan variabel bebas $(\mathrm{X})$ atau dengan kata lain model tersebut layak untuk digunakan.

\section{Tingkat SukuBungaKredit}

Variabel tingkat suku bunga kredit $\left(\mathrm{X}_{1}\right)$ mempunyai koefisien regresi $\left(\mathrm{b}_{1}\right)=$ -25204 dengan probabilitasnya adalah sebesar 0,133. Karena probabilitas 0,133 lebih besar dari taraf nyata yang digunakan $(\alpha=0,05)$, maka hal ini menunjukkan bahwa variabel tingkat suku bunga kredit $\left(X_{2}\right)$ mempunyai hubungan yang negatif dan berpengaruh tidak nyata terhadap investasi sektor pertanian di Sulawesi Tenggara. Sehingga dapat diartikan bahwa

$$
\text { QE Journal | Vol.02 - No.04 - } 10
$$


investasi di sektor pertanian yang dilakukan di Sulawesi Tenggara tidak dipengaruhi oleh tingkat suku bunga kredit namun secara umum hubungan antara tingkat suku bunga kredit dan investasi sektor pertanian memiliki kecendrungan untuk berhubungan negatif. Hal ini didukung oleh Deliarnov (1995), terdapat hubungan negatif antara jumlah investasi dengan tingkat suku bunga. Jika tingkat suku bunga naik, level investasi akan berkurang. Sebaliknya jika tingkat suku bunga rendah, orang akan berbondong-bondong menanamkan investasi diberbagai bidang usaha (sektor rill).

Variabel tingkat suku bunga kredit tidak berpengaruh nyata terhadap investasi sektor pertanian di Sulawesi Tenggara disebabkan karena investor lebih melihat faktor lain yang lebih dominan seperti kontribusi sektor pertanian terhadap Produk Domestik Regional Bruto (PDRB), dimana sektor pertanian memberikan kontribusi terbesar terhadap PDRB Sulawesi Tenggara. Hal ini didukung oleh Suparmoko (2000), menyatakan bahwa faktor lain yang mempengaruhi tinggi rendahnya tingkat investasi adalah pendapatan nasional (pendapatan regional). Serta faktor keamanan di dalam suatu daerah, dimana Provinsi Sulawesi Tenggara merupakan salah satu daerah di Indonesia yang mempunyai tingkat keamanan yang lebih baik jika dibandingkan dengan daerah-daerah lain sehingga dapat memberikan rasa aman kepada investor. Hal ini di dukung oleh Deliarnov (1995), Jika situasi politik aman maka tingkat investasi akan tinggi, dan di dukung oleh hasil penelitian Christianty (2006), kegiatan investasi tidak hanya di pengaruhi oleh tingkat suku bunga akan tetapi dipengaruhi oleh faktor lain seperti situasi politik dan keamanan dalam negeri, keadaan ekonomi, ketidakpastian hukum dan pergantian kepemimpinan negara dan pejabat terkait. Selain itu perubahan tingkat suku bunga hanya berpengaruh pada investor domestik akan tetapi investor asing tidak dipengaruhi oleh tingkat sukubunga.

\section{Produk Domestik Regional Bruto (PDRB) Sektor Pertanian}

Variabel PDRB sektor pertanian $\left(X_{2}\right)$ mempunyai koefisien regresi $\left(b_{2}\right)$ sebesar 0,191 dengan probabilitasnya adalah sebesar 0,0081. Karena probabilitas 0,0081 lebih kecil dari taraf nyata yang digunakan $(\alpha=0,05)$, maka hal ini menunjukkan bahwa variabel PDRB sektor pertanian $\left(\mathrm{X}_{2}\right)$ mempunyai hubungan yang positif dan berpengaruh nyata terhadap investasi sektor pertanian di Sulawesi Tenggara. Nilai koefisien regresi

QE Journal |Vol.02 - No.04 - 11 
sebesar 0,191 menunjukkan bahwa apabila terjadi penambahan atau peningkatan PDRB sektor pertanian sebesar Rp 1 maka akan menyebabkan peningkatan investasi sektor pertanian sebesar $\mathrm{Rp} 0,191$ atau dapat dikatakan bahwa apabila terjadi peningkatan PDRB sektor pertanian sebesar $1 \%$ maka akan menyebabkan investasi sektor pertanian meningkat sebesar 0,97\%, dengan asumsi variabel lain dianggap konstan (cateris paribus). Sehingga dapat dikatakan jika PDRB sektor pertanian meningkat maka akan menyebabkan investasi di sektor pertanian juga akan meningkat.

Variabel PDRB sektor pertanian berpengaruh nyata terhadap investasi sektor pertanian di Sulawesi Tenggara, disebabkan karena dengan meningkatnya pendapatan pada sektor pertanian maka akan menyebabkan semakin banyaknya investor yang tertarik pada sektor tersebut karena dianggap sektor tersebut dapat memberikan keuntungan yang besar. Serta dengan meningkatnya pendapatan maka akan menyebabkan peningkatan pengeluaran konsumsi sehingga untuk memenuhi permintaan tersebut maka dibutuhkan penambahan investasi. Hal ini didukung oleh Partadiredja (1985), salah satu faktor yang mempengaruhi investasi adalah pendapatan nasional. Makin tinggi pendapatan nasional makin tinggi pula pengeluaran konsumsi. Pengeluaran konsumsi yang makin tinggi memerlukan produksi barang-barang konsumsi yang lebih banyak. Produksi barang-barang konsumsi yang lebih banyak memerlukan barangbarang modal yang lebih banyak pula.

\section{SIMPULAN DAN SARAN}

1. Tingkat suku bunga kredit mempunyai hubungan yang negatif dan memberikan pengaruh yang tidak nyata terhadap investasi sektor pertanian.

Produk Domestik Regional Bruto (PDRB) sektor pertanian mempunyai hubungan yang positif dan berpengaruh nyata terhadap investasi sektor pertanian di Sulawesi Tenggara, atau dapat dikatakan jika PDRB sektor pertanian meningkat sebesar $1 \%$ maka akan meningkatkan investasi sektor pertanian sebesar $0,97 \%$. 


\section{DAFTAR PUSTAKA}

BPS. 2010. Sulawesi Tenggara Dalam Angka. Badan Pusat Statistik Provinsi Sulawesi Tenggara. Kendari.

Christanty. Kumpulan Abstrak Skripsi Mahasiswa Sarjana STIEK Tahun 2006. (on line), (www.Perpustakaan Perguruan Tinggi Bogor.com, diakses 7 April 2008).

Deliarnov. 1995. Pengantar Ekonomi Makro. UI Press. Jakarta.

Dornbusch, R. dan S. Fischer. 1987. Macroeconomics. Fourth Edition.McGraw-Hill, New York.

Dumairy. 1996. Perekonomian Indonesia. Erlangga. Jakarta

Koutsoyiannis. 1977. Theory of Econometrics, second edition. The MacmilanPres Limited.The United Kingdom.

Kuncoro, M. 2004. Otonomi Daerah dan Pembangunan Daerah. Erlangga. Jakarta.

Mankiw, N.G. 2000. Macroeconomics. Worth Publishers, New York.

Pangaribuan, N., Edi, K dan Sri, H. 2005. Pengantar Ilmu Pertanian. Universitas Terbuka. Jakarta.

Partadiredja, A. 1985. Pengantar Ekonomika. BPFE Yogyakarta. Yogyakarta.

Rahardja, R dan Mandala. 2005. Teori Ekonomi Makro Suatu Pengantara. Lembaga Penerbit Fakultas Ekonomi UI. Jakarta.

Samuelson dan William. 1994. Ekonomi. Erlangga. Jakarta.

Sukimo, S. 1994. Pengantar Teori Ekonomi Makro. PT Raja Grafindo Persada. Yogyakarta.

Soediyono. 1992. Ekonomi Makro Pengantar Analisis Pendapatan Nasional. Liberty Yogyakarta. Yogyakarta.

Suparmoko. 2000. Pengantar Ekonomika Makro. BPFE Yogyakarta. Yogyakarta.

Tambunan, T. 2003. Perekonomian Indonesia Beberapa Masalah Penting. Ghalia Indonesia. Jakarta.

Thomas, R. L. 1995. Modern Econometrics an Introduction. Department of Economics, Manchester Metropolitan University. TJ Press, Padstow. 